\title{
EKSPERIMEN MOTIF BENTUK FLORA DENGAN MEDIA SABUN MENGGUNAKAN TEKNIK UKIR
}

\author{
Asmayuni ${ }^{*}$, Heri Soe prayogi ${ }^{*}$ \\ Program Studi Pendidikan Seni Rupa Jurusan Seni Rupa Fakultas Bahasa dan Seni \\ Universitas Negeri Medan \\ Jl. Willem Iskandar Pasar V Medan Estate, Kec, Percut Sei Tuan, Kab. Deli Serdang, Kode Pos 20371 \\ Sumatera Utara. Indonesia \\ Email:asmayuni4@gmail.com,herissoe@unimed.ac.id
}

\begin{abstract}
Abstrak
Penelitian ini bertujuan : (1) untuk mendeskripsikan proses pembuatan motif flora dengan teknik ukir menggunakan media sabun batangan. (2) untuk mengetahui hasil dari pembuatan motif flora dengan teknik ukir menggunakan media sabun batang an. (3) untuk mengetahui kelebihan dan kekurangan dari pembuatan motif flora deng an teknik ukir menggunakan media sabun batangan. Metode penelitian yang digunakan adalah metode deskriptif kualitatif Teknik pengumpulan data yang digunakan adalah observasi dan dokumentasi. Penelitian ini dilakukan di SMP Swasta Salsa Percut Sei Tuan. Jumlah populasi penelitian 38 siswa. Teknik peng ambilan s ampel penelitian adalah total sampling, yaitu teknik pengambilan sampel sumber data yang apabila populasi berjumlah dibawah 100 maka sampel adalah keseluruhannya. Data penelitian ini dijaring dari hasil eksperimen, observasi serta penilain oleh 3 orang validator. Dari hasil penelitian diperoleh kesimpulan bahwa hasil eksperimen motif flora dengan media sabun batang an menggunakan teknik ukir dikatakan baik, dilihat dari karya yang di kategori baik di presentasi 36,8\% sedangkan untuk kateg ori cukup baik di presentase $63,2 \%$. sis wa mampu memenuhi standart penilaian yang ditetapkan terhadap siswa deng an minimum nilai yaitu 70 hingga hasil akhir pada proses pembuatan eksperimen motif flora dengan media sabun batangan meng gunakan teknik ukir menunjukkan bahwa 38 siswa mencapai ketuntasan.
\end{abstract}

Kata Kunci: eks perimen, motif flora, sabun, ukir.

\begin{abstract}
This study ai aims: (1) to describe the process of making flora motifs using carving techniques using bar soap media. (2) to determine the results of the making offloralmotifs with carving techniques using bar soap media. (3) to determine the advantages and disadvantages of mak ing flora motifs by using carving techniques using bar soap media. The research method used is descriptive qualitative method. Data collection techniques used are observation and documentation. This research was conducted at the Private Junior High School of Salsa Percut Sei Tuan. The number of research population is 38 students. The research sampling technique wastotal sampling, namely the sampling techniquefor data sources, if the population was below 100, the sample was the whole. The research data was collected from the results of experiments, observations and judgments by 3 validators. From the research results, it is concluded that the experimental results offlo ra motifs with bar soap media using carving techniques are said to be good, seen from the works that are in the good category at the presentation of $36.8 \%$ while for the fairly good category at the percentage of $63.2 \%$. Students are able to meet the standard assessment set for students with a minimum score of 70 until the final result in the process of making experiments with flora motifs using bar soap media using carving techniques shows that 38 students achieve completeness.
\end{abstract}

Keywords: experiments, floral motif, soap, carving.

\section{PENDAHULUAN}

Pendidikan Seni Budaya khususnya dalam mata pelajaran seni rupa ditingkat pendidikan Sekolah Menengah Pertama (SMP) pada umumnya merupakan salah satu mata pelajaran yang masih perlu ditumbuh kembangkan, didalammata pelajaran inibanyak sekali cabang-cabangnya sehingga di satu sekolah tidak mungkin akan menerapkan semua yang terkandung didalamnya. Seperti dalam penempatan keterampilan mengukir untuk siswa SMP masih sangat kurang penerapannya, disamping waktu yang dibebankan pada mata pelajaran seni budaya juga kurangnya skill yang dimiliki guru seni budaya itu sendiri, padahal jika kita 


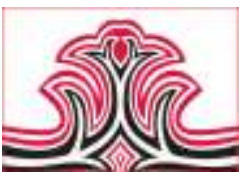

kaitkan dengan kepentingan secara umum peranan pendidikan sangatlah penting.

Salah satu pembelajaran yang ada dalam seni rupa adalah mengukir. Pembelajaran mengukir termuat dalam kurikulum 2013 yang diterapkan di sekolah, meskipun demikian banyak sekolah yang belum menerapkan pembelajaran tersebut. Banyaknya kendala y ang dihadapi mulai dari tenaga peng ajar yang tidak sesuai dengan bidangnya sampai kepada penyediaan alat dan bahan oleh pihak sekolah itu sendiri membuat banyak sekolah tidak menerapkan pembelajaran tersebut. Selain kendala pada media, yang menjadi kendala lainnya adalah penggunaan waktu untuk mengukir karena membutuhkan waktu yang tidak singkat.

Berdasarkan hasil peninjauan awal dengan beberapa sis wa saat praktek mengajar dikelas VIII SMP Swasta Salsa Percut Sei Tuan pada pelaksanaan magang 3 tahun 2019/2020 didapati bahwa pembuatan ukir dengan bahan utama berupa kayu sulit dalam proses pembuatan yang membutuhkan waktu dan tenaga yang lebih. Pembelajaran seni rupa pada sis wa masih pada batas pembelajaran menggambar dan belum mencoba dengan media y ang berbeda. Materi pelajaran seni upa sudah diberikan sesuai dengan kuriku lumyang berlaku di sekolah yaitu kurikulum 2013. Kompetensi dasar mengenai menggambar flora, fauna dan benda alam atau yang biasa disebut dengan ragam hias telah diajarkan, namun pada kompetensi dasar menerapkan ragam hias pada benda keras atau kayu masih belum diajarkan. Selain sulit dalam mendapatkan bahan yang mudah diukir juga sulitnya proses pembuatan yang membutuhkan waktu dan tenaga yang banyak.

Berdasarkan uraian yang telah dipaparkan diatas, permas alahan ini dapat diselesaikan dengan mengganti media kayu dengan media alternatif y aitu benupa sabun batangan. Pembuatan ukir menggunakan bahan sabun batangan sangat mudah untuk dipraktekkan karena sabun batangan mempunyai tekstur yang tidak keras dan juga dapat diperoleh dengan mudah.

\section{KAJIAN TEORI}

\section{Eksperimen}

Menurut Djamarah dan Zain (2006:84), metode eksperimen (percobaan) adalah cara penyajian pelajaran, dimana sis wamelakukan percobaan dengan mengalami dan membuktikan sendiri sesuatu yang dipelajari.

Menurut Ary (2010: 320), berpendapat bahwa "An experimental design is the general plan for carrying
Gorga : Jurnal Seni Rupa

Volume 09 Nomor 02 Juli-Desember 2020

p-ISSN: 2301-5942 | e-ISSN: 2580-2380

out a study with an active independent variable". Yang bararti : Desain eksperimental adalah rencana umum untuk melakukan penelitian dengan variabel independen aktif.

Menurut Batens dan Bendegem (1988: 4), menjelaskan bahwa, "the experimental method is a complex structure in which observation, hypotheses and experimental test find their proper place, so it cannot simply be reduced to the moment in which experimens are performed". Yang bararti : Metode eksperimental adalah struktur kompleks tempat observasi, hipotesis, dan uji eksperimental menemukan tempat yang tepat, sehingga tidak dapat begitu saja direduksi menjadi momen saat eksperimen dilakukan.

Roestiyah (2001:80) mengemukakan bahwa metode eksperimen adalah salah satu cara mengajar, dimana sis wa melakukan suatu percobaan tentang suatu hal, mengamati prosesnya serta menuliskan hasil percobaannya, kemudian hasil pengamatan itu disampaikan ke kelas dan dievaluasi oleh guru.

Berdasarkan beberapa pendapat di atas maka dapat disimpulkan bahwa metode eksperimen adalah cara penyajian pelajaran dengan suatu percobaan, mengalami dan membuktikan sendiri apa yang dipelajari, serta siswa dapat menarik suatu kesimpulan dari proses yang dialami.

\section{Motif Flora}

Menurut Suherman (2005:13), "Motif adalah desain yang dibuat dari bagian-bagian bentuk, berbagai macam garis atau elemen-elemen, yang terkadang begitu kuat dipengaruhi oleh bentuk-bentuk stilasi dan benda, dengan gaya dan ciri khas tersendiri”.

Menurut Sukarman (1982:12), motif flora adalah penggambaran motif tumbuh-tumbuhan dalam seni ornament, sehingga ini terdapat berbag ai jenis, hal itu didasari oleh kesadaran atas pandangan hidup serta pengaruh lingkungan.

Menurut Muksin, dkk (2014:5), bentuk ragam hias motif flora dapat dijumpai disebagian besar dareah di Nusantara. Motif flora merupakan pengembangan dari bentuk asli tumbuhan yang diwujudkan dalam bentuk sulur-uluran.

Dari paparan diatas dapat disimpulkan bahwa motif flora adalah motif yang mengambil sumber objek tumbuh-tumbuhan yang dapat dijumpai di lingkungan. Bentuk yang diambil seperti bunga, 
sulur-sulur, dedaunan dan juga sering digunakan sebagai motif pada batik, ukiran, sulam dan border.

\section{Media}

Menurut Djamarah (2006:121) menjelaskan dalam bukunya :Kata "media" berasal dari bahasa latin dan merupakan bentuk jamak dari kata "medium", yang secara harfiah berarti "perantara atau pengantar". Dengan demikian, media merupakan wahana penyalur informas i belajar atau penyalur pesan. media adalah alat bantu apa saja yang dapat dijadikan sebagai penyalur pesan guna mencapai tujuan pengajaran.

Menurut Susanto (2011:255) mengemukakan bahwa: media yang berarti perantara atau penengah. Biasa dipakai untuk menyebut berbagai hal yang berhubungan dengan bahan (termasuk alat dan teknik) yang dipakai dalam karya seni.

Menurut Gerlach dan Ely (dalam Arsyad 2007:3). Mengatakan bahwa media apabila dipahami secara garis besar adalah manusia, materi atau kejadian yang membangun kondisi yang membuat siswa mampu memperoleh pengetahuan keterampilan atau sikap.

Dari uraian dapat disimpulkan bahwa media adalah alat bantu perantara atau wahana penyalur informasi belajar atau pesan yang membuat siswa mampu memperoleh pengetahuan keterampilan dan sikap guna mencapai tujuan.

\section{Sabun Batangan}

Menurut Zulkifli(2014:173), ia menjelaskan didalam jurnalnya bahwa "Sabun adalah bahan yang digunakan untuk mencuci dan mengemulsi, terdiri dari dua komponen utama yaitu asam lemak dengan rantai karbon $\mathrm{C} 16$ dan sodium atau potasium. Sabun merupakan pembersih yang dibuat dengan reaksi kimia antara kaliumatau natriumdengan asam lemak dari minyak nabati atau lemak hewani. Sabun yang dibuat dengan $\mathrm{NaOH}$ dikenal dengan sabun keras, sedangkan sabun yang dibuat dengan $\mathrm{KOH}$ dikenal dengan sabun lunak".

Menurut BSN (dalam Asri, 2016:126), sabun merupakan campuran dari senyawa natrium dengan asam lemak y ang digunakan sebag ai bahan pembersih tubuh, berbentuk padat, busa dengan atau tanpa zat tambahan lain serta tidak menimbulkan iritasi pada kulit.
Gorga : Jurnal Seni Rupa

Volume 09 Nomor 02 Juli-Desember 2020 p-ISSN: 2301-5942 | e-ISSN: 2580-2380

\section{Ukir}

Menurut Zulkifli dan Triyanto (2018:8), "seni ukir atau ukiran merupakan karya yang dikerjakan dengan teknik pahat (carving) untuk menimbulkan relief sesuai dengan motif yang direcanakan”.

Menurut Soepratno (2004:9), "ukir adalah cukilan berupa ornament ragam hias hasil rangkaian yang indah, berelung-relung saling jalin menjalin, berulang dan sambung menyambung sehing ga mewujudkan suatu hiasan".

\section{METODE PENELITIAN}

Dalam suatu penelitian, metode memegang peranan y ang sangat penting. Hal ini dis ebabkan karena semua kegiatan yang dilakukan dalam penelitian sangat bergantung kepada metode yang digunakan.

Sugiyono (2015:68), metode kualitatif untuk mendapatkan data yang mendalam, suatu data yang mengandung makna. Dalam penelitian ini data diperoleh dengan mengambil sebanyak 38 sampel. Sampel dalam penelitian ini diambil dari teknik total sampling yaitu pengambilan sampel yang apabila jumlah populasi dibawah dari 100 maka sampel adalah keseluruhannya. Data tersebut kemudian di deskripsikan dengan pedoman berdasarkan bentuk, proporsi dan kerapian pada hasil karya.

Adapun metode yang digunakan dalam penelitian ini adalah metode deskriptif kualitatif, metode deskriptif kualitatif yaitu dengan menguraikan masing-masing subjek yang akan diteliti dan disesuaikan dengan kerangka teori yang telah ditetapkan dan teknik pengumpulan data yang digunakan adalah observasi (observation), wawancara (interview) terdahulu dan dokumentasi. Sesuai dengan masalah yang diteliti, maka penelitian ini di laksanakan di Jl. Diponegoro Cinta Rakyat Kecamatan Percut Sei Tuan Kabupaten Deli Serdang provinsi Sumatera Utara. 


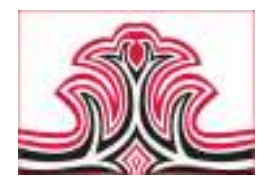

\section{HASIL DAN PEMBAHASAN}

1.Hasil
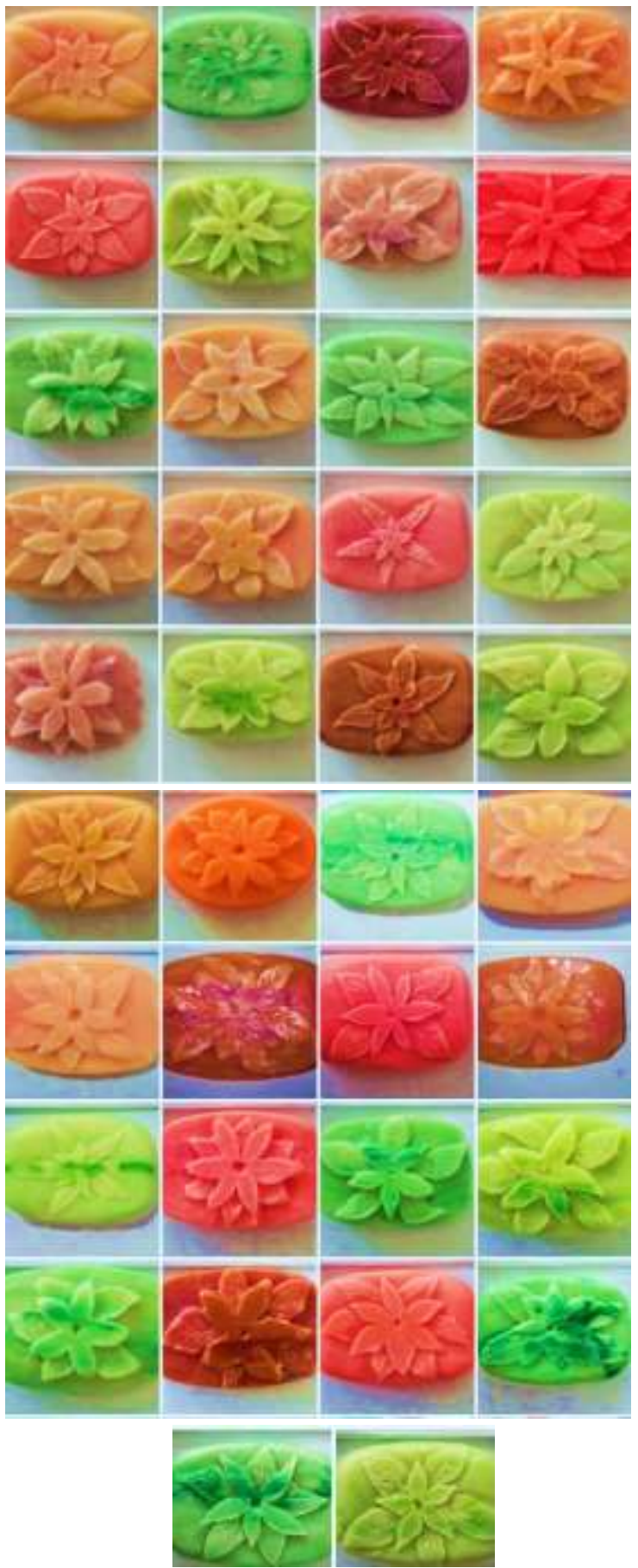

Gambar 1. Kumpulan Hasil Karya Siswa (Asmayuni, 2020)

\section{Pembahasan}

Karya dari Siti Rachel Naholongan. S, dilihat dari segi bentuk memiliki bentuk yang tepat dengan tema yang ditetapkan, pemilihan bentuk dan kejelasan bentuk yang baik, namun kurang pada ketepatan penyusunan kelopak bunga. Dari segi proporsi kary a ini memiliki ukuran, irama dan keselarasan yang baik antara bunga dan daun, namun sedikit kekurangan pada kesatuan kelopak . Dari segi kerapian terlihat baik pada motif,
Gorga : Jurnal Seni Rupa

Volume 09 Nomor 02 Juli-Desember 2020 p-ISSN: 2301-5942 | e-ISSN: 2580-2380

bentuk dan proporsi. Nilai rata-rata dari karya ini adalah 84,1 .

Karya dari Ditya Pratama, dilihat dari segi bentuk memiliki bentuk yang tepat dengan tema yang ditetapkan, kejelas an bentuk dan penyusunan bentuk yang baik, namun kurang pada pemilihan bentuk bunga. Dari segi proporsi karya ini memiliki irama dan kesatuan yang baik namun kurang baik pada ukuran dan keselerasannya. Dari segi kerapian terlihat baik pada motif dan bentuk. Nilai rata-rata dari karya ini adalah 76,3 .

Karya dari Rara Paramita Prayoga, dilihat dari segi bentuk memiliki bentuk yang tepat dengan tema yang ditetapkan, pemilihan bentuk dan kejelasan bentuk yang baik, namun kurang pada ketepatan penyusunan kelopak bunga. Dari segi proporsi karya ini memiliki ukuran, irama dan keselarasan yang baik antara bunga dan daun, namun sedikit kekurangan pada kesatuan kelopak. Dari segi kerapian terlihat baik pada motif, proporsi, dan bentuk. Nilai rata-rata dari karya ini adalah 78,6 .

Karya dari Yosefriyandre, dilihat dari segi bentuk memiliki bentuk yang tepat dengan tema yang ditetapkan dan pemilihan bentuk yang cukup baik, namun kurang pada ketepatan penyusunan dan kejelasan bentuk yang membedakan antara kelopak daun dan bunga. Dari segi proporsi karya ini memiliki ukuran dan irama yang cukup baik, namun ada kekurangan pada kes elarasan dan kes atuan antar bunga dan daun . Dari segi kerapian terlihat cukup baik pada bentuk dan proporsi. Nilai rata-rata dari karya ini adalah 81,6 .

Karya dari Putri Nabila, dilihat dari segi bentuk memiliki bentuk yang tepat dengan tema yang ditetapkan, pemilihan bentuk dan ketepatan penyusunan bentuk yang baik, namun kurang pada kejelasan kelopak bunga yang tampak kurang bervolume. Dari segi proporsi karya ini memiliki irama, kesatuan dan keselarasan yang baik antara bunga dan daun, namun sedikit kekurangan pada ukuran bunga yang kurang seimbang. Dari segi kerapian terlihat baik pada motif, proporsi, warna dan bentuk. Nilai rata-rata dari karya ini adalah 85.5.

Karya dari Amri Aditia Sihombing, dilihat dari segi bentuk memiliki bentuk yang tepat dengan tema yang ditetapkan, penyusunan bentuk yang baik dan pemilihan bentuk yang baik, namun karya ini kurang memiliki kejelasan bentuk pada daun. Dari segi proporsi, karya ini memiliki ukuran yang seimbang, 
keselaras an yang baik dan kesatuan yang baik, namun karya ini tidak memiliki irama yang indah. Dari segi kerapian terlihat baik pada bentuk dan proporsinya. Nilai rata-rata dari karya ini adalah 79,7.

Karya dari Robert Talenta Malau, dilihat dari segi bentuk memiliki bentuk yang tepat dengan tema yang ditetapkan dan pemilihan bentuk yang baik, namun kurang pada kejelasan dan ketepatan penyusunan kelopak bunga. Dari segi proporsi karya ini memiliki ukuran, irama dan keselarasan yang baik antara bunga dan daun, namun sedikit kekurangan pada kesatuan kelopak . Dari segi kerapian terlihat baik pada motif dan proporsi. Nilai rata-rata dari karya ini adalah 76,8 .

Karya dari Intan Nuraini, dilihat dari segi bentuk memiliki bentuk yang tepat dengan tema yang ditetapkan dan kejelas an bentuk, namun kurang pada pemilihan bentuk dan ketepatan penyusunan bentuk. Dari segi proporsi karya ini memiliki ukuran yang seimbang dan kesatuan yang baik namun kurang baik pada irama dan keselerasannya. Dari segi kerapian terlihat baik pada motif dan bentuk. Nilai rata-rata dari karya ini adalah 83.

Karya dari Gani Arya Guna, dilihat dari segi bentuk memiliki bentuk yang tepat dengan tema yang ditetapkan, kejelasan bentuk dan pemilihan bentuk yang baik, namun kurang pada ketepatan penyusunan bentuk. Dari segi proporsi karya ini memiliki ukuran yang seimbang, irama dan kesatuan yang baik namun kurang baik pada keselerasannya. Dari segi kerapian terlihat baik pada motif, proporsi dan bentuk. Nilai ratarata dari karya ini adalah 78,8 .

Karya dari Karina Aura Lubis, dilihat dari segi bentuk memiliki bentuk yang tepat dengan tema yang ditetapkan, ketepatan penyusunan bentuk dan kejelasan bentuk, namun kurang pada pemilihan bentuk kelopak bunga yang tidak seimbang. Dari segi proporsi karya ini memiliki irama, keselarasan dan kesatuan yang baik, namun kurang baik pada ukuran kelopak yang tidak seimbang. Dari segi kerapian terlihat baik pada motif, proporsi dan bentuk. Nilai rata-rata dari kary a ini adalah 77,3

Karya dari Nadin Aulia, dilihat dari segi bentuk memiliki bentuk yang tepat dengan tema yang ditetapkan, pemilihan bentuk dan kejelasan bentuk yang baik, namun kurang pada ketepatan penyusunan kelopak bunga. Dari segi proporsi karya ini memiliki ukuran, irama dan kesatuan yang baik, namun kurang baik pada keselarasan kelopak bunga. Dari segi
Gorga : Jurnal Seni Rupa

Volume 09 Nomor 02 Juli-Desember 2020

p-ISSN: 2301-5942 | e-ISSN: 2580-2380

kerapian terlihat baik pada motif, proporsi dan bentuk Nilai rata-rata dari karya ini adalah 84,2.

Karya dari Muhammad Rafly Alfarizi, dilihat dari segi bentuk memiliki bentuk yang tepat dengan tema yang ditetapkan dan pemilihan bentuk yang cukup baik, namun kurang pada kejelasan bentuk dan ketepatan penyusunan bentuk kelopak bunga yang tidak terlalu jelas. Dari segi proporsi karya ini memiliki , ukuran dan kesatuan y ang baik, namun kurang baik pada irama dan keselaras an kelopak bunga yang tidak ters usun dengan baik. Dari segi kerapian terlihat baik pada motif dan bentuk. Nilai rata-rata dari karya ini adalah 78 .

Karya dari Tegar Prabowo, dilihat dari segi bentuk memiliki bentuk yang tepat dengan tema yang ditetapkan dan pemilihan bentuk yang baik, namun kurang pada ketepatan penyusunan dan kejelasan bentuk kelopak daun. Dari segi proporsi karya ini memiliki ukuran dan irama yang baik, namun ada kekurangan pada kes elarasan dan kes atuan antar bunga dan daun . Dari segi kerapian terlihat baik pada bentuk dan proporsi. Nilai rata-rata dari karya ini adalah 77,8 .

Karya dari Daffa Zonatan, dilihat dari segi bentuk memiliki bentuk yang tepat dengan tema yang ditetapkan, pemilihan bentuk dan kejelasan bentuk yang baik, namun kurang pada ketepatan penyusunan bentuk bunga. Dari segi proporsi karya ini memiliki irama dan kesatuan yang baik namun kurang baik pada ukuran dan keselerasannya. Dari segi kerapian terlihat baik pada motif dan proporsinya. Nilai rata-rata dari karya ini adalah 78,4.

Karya dari Muhammad Dimas Syahputra, dilihat dan segi bentuk memiliki bentuk yang tepat dengan tema yang ditetapkan, ketepatan penyusunan bentuk dan pemilihan bentuk, namun kurang pada kejelasan bentuk kelopak bunga yang tidak terlalu jelas. Dari segi proporsi karya ini memiliki irama, keselarasan dan kesatuan yang baik, namun kurang baik pada ukuran kelopak bunga yang tidak s eimbang dengan daun. Dari segi kerapian terlihat baik pada motif, proporsi dan bentuk. Nilai rata-rata dari karya ini adalah 77,1 .

Karya dari Akbar Prayoga, dilihat dari segi bentuk memiliki bentuk yang tepat dengan tema yang ditetapkan, penyusunan bentuk yang sudah tepat serta kejelasan bentuk yang baik, namun karya ini belum mencapai pemilihan bentuk yang indah. Dari segi proporsi memiliki ukuran yang seimbang, irama yang indah, sertakesatuan yang baik, namun karya ini belum mencapai keselarasan yang indah. Dan dari segi 
kerapian terlihat baik dari motif dan proporsinya. Nilai rata-rata dari karya ini adalah 85,2.

Karya dari Deswita Maharani, dilihat dari segi bentuk memiliki bentuk yang tepat dengan tema yang ditetapkan, pemilihan bentuk dan penyusunan bentuk yang baik, namun kurang pada kejelasan bentuk daun. Dari segi proporsi karya ini memiliki irama dan kesatuan yang baik namun kurang baik pada ukuran dan keseleras annya. Dari segi kerapian terlihat baik pada bentukdan proporsinya. Nilai rata-rata dari karya ini adalah 81,1

Karya dari Gatot Tri Wibowo, dilihat dari segi bentuk memiliki bentuk yang tepat dengan tema yang ditetapkan, pemilihan bentuk dan ketepatan penyusunan bentukyang baik, namun kurang kejelasan pada kelopak bunga. Dari segi proporsi karya ini memiliki ukuran yang simbang, irama dan keselarasan yang baik antara bunga dan daun, namun sedikit kekurangan pada kesatuan kelopak daun. Dari segi kerapian terlihat baik pada motif, proporsi, dan bentuk Nilai rata-rata dari karya ini adalah 77,2 .

Karya dari Meisyla Ananda Syah, dilihat dari segi bentuk memiliki bentuk yang tepat dengan tema yang ditetapkan, pemilihan bentuk dan ketepatan penyusunan bentuk yang baik, namun kurang pada kejelasan kelopak bunga yang tampak kurang bervolume. Dari segi proporsi karya ini memiliki irama, kesatuan dan keselarasan yang baik antara bunga dan daun, namun sedikit kekurangan pada ukuran bunga yang kurang seimbang. Dari segi kerapian terlihat baik pada motif, proporsi, dan bentuk. Nilai rata-rata dari karya ini adalah 85,3.

Karya dari Robby Surya N. Batubara, dilihat dari segi bentuk memiliki bentuk yang tepat dengan tema yang ditetapkan dan pemilihan bentuk yang cukup baik, namun kurang pada ketepatan penyusunan dan kejelas an bentuk bunga. Dari segi proporsi karya ini memiliki ukuran dan irama yang cukup baik, namun ada kekurangan pada keselarasan dan kesatuan antar bunga dan daun . Dari segikerapian terlihat cukup baik pada motif dan proporsi. Nilai rata-rata dari karya ini adalah 76,7 .

Karya dari Sabitha Helena, dilihat dari segi bentuk memiliki bentuk yang tepat dengan tema yang ditetapkan, pemilihan bentuk dan ketepatan penyusunan bentuk yang baik, namun kurang pada kejelasan kelopak bunga yang tampak kurang bervolume. Dari segi proporsi karya ini memiliki ukuran yang seimbang, irama dan kesatuan yang baik
Gorga : Jurnal Seni Rupa

Volume 09 Nomor 02 Juli-Desember 2020

p-ISSN: 2301-5942 | e-ISSN: 2580-2380

antara bunga dan daun, namun s edikit kekurangan pada keselarasan bentuk bunga. Dari segi kerapian terlihat baik pada motif, proporsi dan bentuk. Nilai rata-rata dari karya ini adalah 82.

Karya dari Widya Nur Hasanah, dilihat dari s egi bentuk memiliki bentuk yang tepat dengan tema yang ditetapkan dan pemilihan bentuk yang baik, namun kurang pada ketepatan penyusunan dan kejelasan bentuk yang membedakan antara kelopak daun dan bunga. Dari segi proporsi karya ini memiliki ukuran dan irama yang baik, namun ada kekurangan pada keselarasan dan kesatuan antar bunga dan daun . Dari segi kerapian terlihat baik pada bentuk dan proporsi. Nilai rata-rata dari karya ini adalah 85,7.

Karya dari Sella Oktavia, dilihat dari segi bentuk memiliki bentuk yang tepat dengan tema yang ditetapkan, pemilihan bentuk dan ketepatan penyusunan bentuk yang baik, namun kurang pada kejelasan kelopak bunga yang tampak kurang bervolume. Dari segi proporsi karya ini memiliki ukuran yang seimbang, irama dan kesatuan yang baik antara bunga dan daun, namun sedikit kekurangan pada keselarasan bentuk bunga. Dari segi kerapian terlihat baik pada motif, proporsi dan bentuk. Nilai rata-rata dari karya ini adalah 87,3.

Karya dari Jaka Wijaya, dilihat dari segi bentuk memiliki bentuk yang tepat dengan tema yang ditetapkan dan pemilihan bentuk yang cukup baik, namun kurang pada ketepatan penyusunan dan kejelasan bentuk yang membedakan antara kelopak daun dan bunga. Dari segi proporsi karya ini memiliki ukuran dan irama yang cukup baik, namun ada kekurangan pada kes elarasan dan kes atuan antar bunga dan daun . Dari segi kerapian terlihat cukup baik pada motif dan proporsi. Nilairata-rata darikarya ini adalah 77,4 .

Karya dari Hendi, dilihat dari segi bentuk memiliki bentuk yang tepat dengan tema yang ditetapkan, pemilihan bentuk dan ketepatan penyusunan bentuk yang baik, namun kurang kejelas an pada kelopak daun. Dari segi proporsi karya ini memiliki ukuran yang simbang, irama dan kesatuan keselarasan yang baik antara bunga dan daun, namun s edikit kekurangan pada keselarasan kelopak daun dengan bunga. Dari segi kerapian terlihat baik pada motif dan bentuk. Nilai ratarata dari karya ini adalah 77,3 .

Karya dari Nico Sanjaya, dilihat dari segi bentuk memiliki bentuk yang tepat dengan tema yang ditetapkan dan pemilihan bentuk yang cukup baik, 
namun kurang pada ketepatan penyusunan dan kejelas an bentuk daun. Dari segi proporsi karya ini memiliki ukuran dan irama yang cukup baik, namun ada kekurangan pada keselarasan dan kesatuan antar bunga dan daun . Dari segi kerapian terlihat cukup baik pada motif dan proporsi. Nilai rata-rata dari karya ini adalah 76,1 .

Karya dari Wenny Tania Angeline, dilihat dari segi bentuk memiliki bentuk yang tepat dengan tema yang ditetapkan, pemilihan bentuk dan ketepatan penyusunan bentuk yang baik, namun kurang pada kejelasan kelopak bunga yang tampak kurang bervolume. Dari segi proporsi karya ini memiliki ukuran yang seimbang, irama dan kesatuan yang baik antara bunga dan daun, namun sedikit kekurangan pada keselaras an bentuk kelopak bunga. Dari segi kerapian terlihat baik pada motif, proporsi dan bentuk. Nilai ratarata dari karya ini adalah 78,5.

Karya dari Jessica Darvita Novin, dilihat dari segi bentuk memiliki bentuk yang tepat dengan tema yang ditetapkan dan ketepatan penyusunan bentuk, namun kurang pada pemilihan bentuk dan kejelasan bentuk sehing ga bentuk daun tidak terlihat jelas. Dari segi proporsi karya ini memiliki irama dan kesatuan yang baik, namun kurang baik pada ukuran yang tidak seimbang dan keselerasannya. Dari segi kerapian terlihat baik pada motif dan bentuk. Nilai rata-rata dan karya ini adalah 76,5 .

Karya dari Sufina Azizah, dilihat dari segi bentuk memiliki bentuk yang tepat dengan tema yang ditetapkan, pemilihan bentuk dan ketepatan penyusunan bentuk yang baik, namun kurang pada kejelasan kelopak bunga yang tampak kurang bervolume. Dari segi proporsi karya ini memiliki irama, kesatuan dan keselarasan y ang baik antara bunga dan daun, namun sedikit kekurangan pada ukuran bunga yang kurang seimbang. Dari segi kerapian terlihat baik pada motif, proporsi, warna dan bentuk. Nilai rata-rata dari karya ini adalah 81,2.

Karya dari Muhammad Pareza Putra, dilihat dari segi bentuk memiliki bentuk yang tepat dengan tema yang ditetapkan dan pemilihan bentuk yang baik, namun kurang pada ketepatan penyusunan dan kejelasan bentuk yang membedakan antara kelopak daun dan bunga. Dari segi proporsi karya ini memiliki ukuran dan irama yang cukup baik, namun ada kekurangan pada keselarasan dan kesatuan antar bunga dan daun . Dari segi kerapian terlihat baik pada bentuk dan proporsi. Nilai rata-rata dari karya ini adalah 77,2.
Gorga : Jurnal Seni Rupa

Volume 09 Nomor 02 Juli-Desember 2020

p-ISSN: 2301-5942 | e-ISSN: 2580-2380

Karya dari Ramadhan Syahfitrah, dilihat dari segi bentuk memiliki bentuk yang tepat dengan tema yang ditetapkan, pemilihan bentuk dan ketepatan penyusunan bentuk yang baik, namun kurang pada kejelasan kelopak bunga yang tampak kurang bervolume. Dari segi proporsi karya ini memiliki ukuran yang seimbang, irama dan kes atuan yang baik antara bunga dan daun, namun sedikit kekurangan pada keselarasan bentukbungadan daun. Dari segi kerapian terlihat baik pada motif, proporsi, dan bentuk. Nilai rata-rata dari karya ini adalah 78,2.

Karya dari Muhammad Faiz Ramadhan, dilihat dari segi bentuk memiliki bentuk yang tepat dengan tema y ang ditetapkan dan pemilihan bentukyang cukup baik, namun kurang pada ketepatan penyusunan dan kejelasan bentuk bunga. Dari segi proporsi karya ini memiliki ukuran dan irama yang cukup baik, namun ada kekurangan pada keselarasan dan kesatuan antar bunga dan daun . Dari s egi kerapian terlihat cukup baik pada motif dan proporsi. Nilai rata-rata dari karya ini adalah 77,4

Karya dari M. Gilang Fauzi, dilihat dari segi bentuk memiliki bentuk yang tepat dengan tema yang ditetapkan dan pemilihan bentuk yang cukup baik, namun kurang pada ketepatan penyusunan dan kejelasan bentuk daun. Dari segi proporsi karya ini memiliki ukuran dan irama yang cukup baik, namun ada kekurangan pada keselarasan dan kesatuan antar bunga dan daun . Dari segi kerapian terlihat cukup baik pada motif dan proporsi. Nilai rata-rata dari karya ini adalah 77,2.

Karya dari Ahmad Fauzan Lubis, dilihat dari segi bentuk memiliki bentuk yang tepat dengan tema yang ditetapkan dan pemilihan bentuk yang cukup baik, namun kurang pada ketepatan penyusunan dan kejelasan bentuk bunga. Dari segi proporsi karya ini memiliki ukuran dan irama yang cukup baik, namun ada kekurangan pada keselarasan dan kesatuan antar bunga dan daun . Dari segi kerapian terlihat cukup baik pada motif dan proporsi. Nilai rata-rata dari karya ini adalah 75,5.

Karya dari Tasya Nita Aulia, dilihat dari segi bentuk memiliki bentuk yang tepat dengan tema yang ditetapkan, pemilihan bentuk dan ketepatan penyusunan bentuk yang baik, namun kurang pada kejelasan kelopak bunga yang tampak kurang bervolume. Dari segi proporsi karya ini memiliki ukuran yang seimbang, irama dan kesatuan yang baik antara bunga dan daun, namun s edikit kekurangan pada keselaras an bentuk bunga. Dari segi kerapian terlihat 
baik pada motif, proporsi dan bentuk. Nilai rata-rata dari karya ini adalah 79.

Karya dari Ratih Dwi Amelia, dilihat dari segi bentuk memiliki bentuk yang tepat dengan tema yang ditetapkan, pemilihan bentuk dan kejelasan bentuk yang baik, namun kurang pada ketepatan penyusunan kelopak bunga. Dari segi proporsi karya ini memiliki ukuran, irama dan keselarasan y ang baik antara bunga dan daun, namun sedikit kekurangan pada kesatuan kelopak. Dari segi kerapian terlihat baik pada motif, proporsi, dan bentuk. Nilai rata-rata dari karya ini adalah 77,9 .

Karya dari Aisyah Aulia, dilihat dari segi bentuk memiliki bentuk yang tepat dengan tema yang ditetapkan, pemilihan bentuk dan ketepatan penyusunan bentuk yang baik, namun kurang pada kejelasan kelopak bunga yang tampak kurang bervolume. Dari segi proporsi karya ini memiliki ukuran yang seimbang, irama dan kesatuan yang baik antara bunga dan daun, namun s edikit kekurangan pada keselaras an bentukbungadan daun. Dari segi kerapian terlihat baik pada motif, proporsi, warna dan bentuk. Nilai rata-rata dari karya ini adalah 82 .

Karya dari Hilda Muthya Eka Rahma, dilihat dari segi bentuk memiliki bentuk yang tepat dengan tema yang ditetapkan, pemilihan bentuk dan ketepatan penyusunan bentuk yang baik, namun kurang pada kejelasan kelopak bunga yang tampak kurang bervolume. Dari segi proporsi karya ini memiliki ukuran yang seimbang, irama dan kesatuan yang baik antara bunga dan daun, namun sedikit kekurangan pada keselarasan bentuk daun yang kurang seimbang. Dari segi kerapian terlihat baik pada motif, proporsi dan bentuk. Nilai rata-rata dari karya ini adalah 83,1 .

\section{KESIMPULAN DAN SARAN \\ 1.Kesimpulan}

Berdasarkan hasil penelitian dan pembahasan mengenai eksperimen motif flora dengan media sabun batangan menggunakan teknik ukir pada siswa kelas VIII SMP Swasta Sals a Percut Sei Tuan di tinjau dari proses pembuatan, hasil karya dan kelebihan serta kekurangan media sabun batangan, maka dapat disimpulkan hasil karya dari eksperimen motif flora dengan media sabun batangan menggunakan teknik ukir pada siswa kelas VIII SMP Swasta Salsa Percut Sei Tuan secara keseluruhan sudah baik. Sehingga terbukti pada perolehan nilai akhir yang dicapai dari ketiga indikator penilaian yang meliputi bentuk, proporsi dan kerapian bahwa sis wa mampu memenuhi standart penilaian yang ditetapkan terhadap siswa
Gorga : Jurnal Seni Rupa

Volume 09 Nomor 02 Juli-Desember 2020

p-ISSN: 2301-5942 | e-ISSN: 2580-2380

dengan minimum nilai y aitu 70 hingga hasil akhir pada proses pembuatan eksperimen motif flora dengan media sabun batangan menggunakan teknik ukir menunjukkan bahwa 38 siswa mencapai ketuntasan.

Dilihat dari segi proses pembuatan, kelebihan ukiran dengan media sabun batangan dalam proses pembuatannya tergolong cepat dan mudah dibentuk apa saja, hal tersebut dikarenakan teks tur sabun batangan yang tidak terlalu keras sehing ga memudahkan siswa untuk mengukirnya. Selain itu, sabun juga termasuk bahan yang mudah didapatkan dimana saja serta memiliki aroma atau bau yang sangat wangi, sehingga cocok jika diletakkan diruang keluarga, tamu ataupun kamar tidur. Dari segi produk, ukiran dengan media sabun batangan tidak kalah dengan ukiran berbahan kayu dalam hal detail pada motif dan bentuk. Hasil ukirannya pun tidak kalah bagus dengan ukiran berbahan kayu.

Ukiran dengan media sabun batangan juga memiliki kekurangan. Kekurangan dalam proses pembuatan ukiran yaitu faktor kegagalan yang cukup tinggi apabila membuatnya menggunakan peralatan yang tidak sesuai, sehingga mudah patah jika tidak berhati-hati. Dari segibahannya yang terbuat dari sabun maka bahan ters ebut tidak tahan terhadap air atau ru sakjika terkena air, tidak tahan benturan sehingga tidak dapat dikirim ke tempat yang jauh jika tidak membawanya dengan hati-hati.

\section{Saran}

Berdas arkan kesimpulan di atas, maka sebagai tindak lanjut penelitian ini dis arankan hal-hal sebagai berikut: Bagi pihak sekolah maupun dinas pendidikan diharapkan untuk dapat lebih mengembangkan dan memanfaatkan bahan-bahan sekitar yang bisa dijadikan sebagai bahan pembuatan kerajinan bagi siswa dan siswi seperti contohnya sabun batangan, sehingga pengetahuan siswa dapat bertambah mengenai banyaknya macam bahan yang bisa dimanfaatkan sebagai bahan pengajaran. Bagi mas yarakat, penelitian ini dapat dijadikan sebagai referensi peluang usaha baru dan sumber pemasukan dalam bidang kerajinan tangan. Untuk peneliti selanjutnya yang ingin meneliti tentang karya ukir berbahan sabun batangan supaya memperluas dan mengembangkan motif-motif yang bis a dikembangkan.

\section{DAFTAR RUJUKAN}

Arsyad, A. (2007). Media Pembelajaran. Jakarta: Raja Gravindo Persada. 
Ary, D. Jacobs, L.C. Sorencen, C. dan Rajavieh, A. (2010). Introduction To Research in Education. USA: Wadsworth.

Asmayuni. (2020). "Hasil Karya Siswa". Hasil Dokumentasi Pribadi: 06 oktober 2020, SMP Swasta Salsa.

Batens, D. dan Bendegem, J.P.V. (1988). Theory And Experiment : Recent Insights And New Persperctives On Their Relation. Holland: D. Reidel Publishing Company.

Djamarah, S.B. dan Zain, A. (2006). Strategi Belajar Mengajar. Jakarta: Rineka Cipta.

Suherman, H. (2005). Motif Hias Indonesia. Yogyakarta: Adicita Karya Nusa.

Muksin, dkk. (2014). Seni Budaya. Jakarta: Kementrian Pendidikan dan Kebudayaan.

Roestiyah, N. K. (2001). Strategi Belajar Mengajar. Jakarta: Rineka Cipta.

Soepratno. (2004). Ornamen Ukir Kayu Tradisional Jawa. Semarang: PT. Effhar Offset.

Sukarman. (1982). Pengantar Ornament Timur, Yogyakrata:Sub/Bag Proyek STSRI “ASRI”.

Sus anto, M. (2011). Diksi Rupa. Yogyakarta:Dicti Art Lab.

Asri, W., dkk. (2016). Pembuatan Sabun Padat Transparan Menggunakan Minyak Kelapa Sawit (Palm Oil) Dengan Penambahan Bahan Aktif Ekstrak The Putih. Jurnal Pertanian Lampung, 5(3), 165-174.

Zulkifli, Mochamad dan Teti Estiasih. (2014). Sabun Dari Distilat Asam Lemak Minyak Sawit: Kajian Pustaka. Jurnal Pangan dan Agroindustry, 2(4), 184-198.

Zulkifli dan Triyanto, R. (2018). Nirmana Dwimatra (Elemen, Prinsip Dan Aplikasi Teknis Seni Rupa Dan Desain). Medan: FBS Unimed Press. 